\title{
ANTROPOLOGIA. E INTERNET: QUANDO O "CAMPO" É A CIDADE E O COMPUTADOR É A "REDE"
}

\author{
Jonatas Dornelles \\ Universidade Federal do Rio Grande do Sul ${ }^{*}$ - Brasil
}

Resumo: Artigo que apresenta uma reflexão sobre a estreita associação que atualmente se processa entre computador/Internet e condutas sociais. Um dos aspectos mais claros está relacionado ao cultivo de um tipo de sociabilidade que podemos denominar como sendo "virtual". Esse conceito surge do encontro de determinadas características. De um lado, temos a presença de práticas de sociabilidade ao "modo clássico", sendo mantida pelo encontro face a face. De outro, está presente a especificidade gerada por tal tecnologia: a presença da interface gráfica como mediador do encontro social.

Palavras-chave: antropologia urbana, Internet, novas tecnologias, sociabilidade virtual.

Abstract: Article that presents a reflection about the narrow association that now is processed between computer/Internet and social conducts. One of the clearest aspects is related to the cultivation of a sociability type that we can denominate as being "virtual". That concept appears of the encounter certain characteristics. On a side we have the presence of sociability practices to the "classic" way, being maintained by the encounter face to face. Of other, it is present the especific generated by such technology: the presence of the graphic interface as mediator of the social encounter.

Keywords: Internet, new technologies, sociability virtual, urban anthropology.

* Doutorando em Antropologia Social.

Horizontes Antropológicos, Porto Alegre, ano 10, n. 21, p. 241-271, jan./jun. 2004 
Contemporaneamente parece que a informática já está banalizada. Quando me refiro a ela como algo banal, estou me referindo antes à difusão de sua idéia do que à sua penetração nos diversos estratos sociais. Existem pesquisas sobre condições socioeconômicas que regularmente divulgam o percentual de pessoas que têm acesso ao conjunto computador/Internet. De maneira geral, os dados revelam que a maior parte dos usuários de computadores/Internet é composta por pessoas com médio e alto poder aquisitivo.

A tecnologia informática ainda é cara. No Brasil um aparelho novo de computador é vendido, em média, por 1.500 reais. Considerando que o salário mínimo atual é de 240 reais, então um computador pessoal custa em torno de seis vezes esse indicador. Embora o mercado tenha gerado uma série de condições que facilitam a compra do aparelho - em vista da grande demanda - ainda assim é uma aquisição dispendiosa. Devido a essas condições, ainda não é uma tecnologia que atingiu as massas na forma de bem de consumo, tal como já aconteceu com a televisão e, muito antes, com o rádio.

Quando me refiro à banalização da informática, estou tratando da vulgarização do reconhecimento da existência da tecnologia. Talvez as pesquisas quantitativas devessem questionar também o fato da população saber da existência de computador/Internet. Falta um dado que, paralelo ao que se refere à posse de computador/Internet, indique a difusão da idéia da informática e da mídia digital. Possivelmente uma investigação desse tipo indicaria um alto percentual de "reconhecimento da existência" de computadores/Internet e seus usos. Um primeiro indicativo de massificação da idéia está no seguinte fato: recorrentemente surgem nos programas de televisão discussões sobre o tema. E, sendo assim, a mídia digital (no caso do computador/Internet) vai sendo divulgada, via mídia eletrônica (televisão) para a massa da população.

Atualmente o tema computador/Internet atingiu o senso comum da população. É cada vez mais comum e compreensível que seja possível bater papo, conhecer pessoas, fazer amigos e até mesmo namorar via computador/Internet. Há uns três anos esses temas levantavam dúvidas, desconfiança e muito mais discussão nos veículos de comunicação, principalmente na televisão. Hoje a situação parece ter se acomodado em decorrência de uma familiarização com o fenômeno. O panorama é menos de questionamentos sobre a possibilidade de existir relacionamento social via Internet e mais de tomada de opinião sobre a questão. 
Adiante tentarei conduzir o leitor em uma reflexão sobre a sociabilidade que está relacionada com o computador/Internet. Utilizarei como campo a cidade de Porto Alegre e as salas de bate-papo virtual (chat) relacionadas a ela, em pesquisa etnográfica desenvolvida de 2001 a 2003. Nesse caso, o recorte se dará a partir do chat do provedor Terra sob o título "Porto Alegre". ${ }^{1}$ Em vista desse recorte irei iniciar do ponto em que a Internet se insere no contexto da cidade. Esse foi um processo específico. Em cada lugar há a conjunção de condições amplas (nacionais ou mundiais) e fatores específicos e determinados pela cultura local. Em Porto Alegre o conjunto computador/Internet começou a ter uma difusão acelerada a partir da metade da década de 1990.

\section{Evolucão digital}

Em solo porto-alegrense a tecnologia informática floresceu sobre as bases deixadas pela televisão, que começou a ser difundida pelo mundo a partir da metade do século XX. Esse novo invento mesclava as características de dois outros já difundidos: o cinema e o rádio. Do primeiro vinha a questão audiovisual. Do segundo, a transmissão a partir de ondas eletromagnéticas. Como resultado, a humanidade conheceu o mais poderoso meio de comunicação de massa ${ }^{2}$ surgido até então. A relação nesse tipo de comunicação se estabelecia entre "um" e "muitos". Na televisão a situação envolve uma emissora enviando imagens e som através de um canal a uma massa de espectadores.

Com a televisão surgiu mais um veículo de comunicação para compor a mídia eletrônica, que até então era formada pelo cinema e pelo rádio. "Eletrônica" porque utilizava o sistema tecnológico dessa categoria para a sua difusão. Até então o que existia era a mídia impressa, composta pelos veículos de comunicação que utilizavam a impressão: livros, jornais e revistas. A mídia eletrônica não exterminou a impressa, as duas vindo a dividir espaço.

\footnotetext{
1 Artigo baseado na dissertação de mestrado Planeta Terra, Cidade Porto Alegre: uma etnografia entre internautas, defendia em dezembro 2003 sob a orientação da $\operatorname{Prof}^{\mathrm{a}} \operatorname{Dr}^{\mathrm{a}}$ Cornelia Eckert. Estudo que reflete sobre o cenário atual, em que a cidade de Porto Alegre é envolvida pela informática e a sociabilidade dos porto-alegrenses gira em torno dos modos on e off-line de contato (Dornelles, 2003).

${ }^{2} \mathrm{O}$ que deve ser definido como a comunicação simultânea a uma ampla, anônima e heterogênea faixa de público.
} 
Na metade do século XX a tecnologia do rádio se difundia por Porto Alegre. As ondas radiofônicas traziam o mundo aos porto-alegrenses. Através dos aparelhos de rádio a população foi rapidamente informada sobre o fim da Segunda Guerra e a partilha da Palestina. Mas o rádio não servia somente à informação, ele também entretinha. Pesquisas sobre Porto Alegre apontam que em 1956 o maior sucesso do rádio na cidade era o Programa Maurício Sobrinho. Ele era transmitido diretamente do palco do Cine Castelo, na rua da Azenha. Ali se apresentavam tanto os sucessos do momento, como Ângela Maria e Cauby Peixoto, como os ainda desconhecidos da época, como era o caso de Elis Regina, que se apresentava como caloura. A presença dos porto-alegrenses era maciça tanto dentro do edifício, no palco, quanto do lado de fora, à espera das estrelas. Em 1959 outra inovação tecnológica na cidade: a TV Piratini, canal 5 de Porto Alegre. Nessa época a programação ia das $20 \mathrm{~h}$ até as $22 \mathrm{~h}$. Os programas eram apresentados ao vivo, já que não existia videoteipe. ${ }^{3}$

Em meados da década de 1970 os jogos eletrônicos em casas especializadas (fliperamas) eram a sensação entre os jovens portoalegrenses. Na década de 1980 começou a se popularizar uma nova forma de tecnologia: os videogames. Eles eram aparelhos que, conectados à televisão, geravam imagens de jogos. O jogador poderia, via "controle" (um peça de uns $15 \mathrm{~cm}$ de lado, com uma alavanca e um botão), operar as imagens projetadas na televisão e jogar o jogo. Os aparelhos de televisão também estavam se popularizando. Era cada vez mais difícil existir alguma residência na cidade que não possuísse um aparelho de TV. Naquela época ainda existiam os aparelhos coloridos e os preto-e-branco. Quem tinha uma TV com controle remoto... era luxo.

Se na década de 1980 a sensação entre os jovens era o videogame, nos anos 1990 floresceu a informática. Os videogames continuaram ficando cada vez mais aperfeiçoados, mas agora existia algo diferente que proliferava no mundo e chamava a atenção em Porto Alegre: o computador pessoal. Desde a década anterior já se sabia da sua existência. Naquela época os modelos eram os "XP" (xispê). A partir de meados da década de 1990 o equipamento começou a se difundir entre a população. Primeiramente ele foi absorvido pela classe alta. Logo em seguida pela classe média. Junto com o deslumbre do aparelho vinha outra sensação: a Internet.

\footnotetext{
Fita magnética que grava as imagens do programa, possibilitando transmiti-lo em outro momento, depois de sua produção. Nos programas "ao vivo" a produção e a exibição dos programas coincidem.
}

Horizontes Antropológicos, Porto Alegre, ano 10, n. 21, p. 241-271, jan./jun. 2004 
A Internet surgiu nos planos norte-americanos de combate à União Soviética. A idéia da Internet, surgida na década de 1970, era possibilitar uma comunicação no formato de rede que não tivesse nenhum centro. Dessa maneira seria quase impossível ao inimigo combater esse novo meio de comunicação. Cada "nó" da rede (Internet) era autônomo na produção de mensagem e divulgação da mesma para os outros "nós". Ao contrário da televisão, a Internet possibilita a comunicação entre "muitos" e "muitos". Isso está relacionado com o potencial "produtor" que a nova mídia possibilita. Multiplicam-se os canais (na rede/Internet) que divulgam informações e tratam de "ser ouvidos". Agora muitos são os produtores de informação e eles estão de todos os lados, não somente do lado de uma classe dominante econômica ou politicamente (onde poderíamos situar as emissoras de televisão).

O computador/Internet faz parte de um conjunto de meios de comunicação embasados pela tecnologia digital - mídia digital. Com esse novo suporte (diferente do impresso e do eletrônico) é possível transmitir a informação sem distinção (imagem, vídeo, voz e dados) na forma de bits e bytes. ${ }^{4}$ Nas últimas duas décadas a expansão da rede superou a de qualquer outro invento do ser humano (comparando a quantidade de indivíduos que a utilizam e quanto tempo levou para atingir esse patamar ${ }^{5}$ ). Atualmente o número de sites publicados na Internet chega a cifra dos milhões.

O meio de comunicação propiciado pela Internet possibilita a comunicação em escala mundial. A partir da rede são colocados à disposição canais de comunicação entre diferentes partes do globo terrestre. A partir dela os indivíduos podem compartilhar informações (na forma de imagem, voz ou dados) em fração de segundos, mesmo situados em continentes diferentes. Esse panorama faz pensar que essa tecnologia corrobora a integração mundial, que é pregada pelo modelo de globalização iniciado no século XX e resultante dos avanços do capitalismo. O resultado é visível em uma potencial heterogeneidade de informações disponibilizadas, tanto quanto

${ }^{4}$ Bit é a unidade mínima de um sistema digital. Ele opera no código binário formado por 0 e 1. Byte é uma seqüência de bits que representa uma informação, geralmente um caractere alfanumérico.

${ }^{5}$ Enquanto o rádio levou 38 anos para atingir a meta de 50 milhões de usuários (desde a concepção de sua idéia inicial) e o computador pessoal 16, a Internet levou apenas quatro anos para atingir o mesmo índice. 
uma diversidade de usuários. Isso significa que diferentes manifestações culturais são divulgadas via Internet para o resto do mundo. Seguindo a forma da Internet (comunicação entre "muitos" e "muitos"), vários são os produtores e consumidores de informação. Fica claro um panorama onde prevalece a heterogeneidade e a diversidade de estilos de vida e manifestações culturais. Porém, o leitor deve ser alertado que esse cenário pode assim ser conceitualizado quando consideramos o conjunto da rede, a Internet toda em sua dimensão mundial.

Em solo brasileiro a Internet foi tomando forma na metade da década de 1990. Em 1995 o Ministério das Comunicações e o Ministério da Ciência e Tecnologia começaram a incentivar a criação de provedores privados de acesso à Internet. Até então o acesso era gerenciado por órgãos de pesquisa (como o CNPq) e governamentais. Em 1996 a Prefeitura de Porto Alegre inaugurou o seu provedor de acesso à Internet: a Portoweb. Logo em seguida surgiram diversos provedores privados sediados na cidade: Conex, ZAZ (que mais tarde se transformou em Terra), Matrix, etc.

Até o final da década de noventa os porto-alegrenses viam na cidade uma difusão cada vez maior do "aparelho computador" e do acesso à Internet. Rapidamente várias residências, escritórios e estabelecimentos comerciais passaram a possuir um computador e uma conexão à Internet. Aos jovens que ingressaram no mercado de trabalho nessa época talvez não fosse tão impactante a nova tecnologia. Porém a possibilidade de enviar um documento via e-mail, a troca de informações via Internet e o acesso a sites de empresas, entre tantas possibilidades, transformava a vida em Porto Alegre. A cada dia surgiam novas lojas especializadas em equipamentos de informática. Surgiram até feiras dedicadas ao segmento. Nelas era possível comprar equipamentos e peças mais baratas que o normal do mercado. Logo também foi possível perceber uma mudança na linguagem dos portoalegrenses. Eles começaram a tratar de assuntos novos: "te mando um $e$ mail", "acessa meu site", "já foi nesse chat?", "qual o teu provedor?”... Rapidamente também a conexão à Internet deixou de ser "discada"6 para ser "via cabo". ${ }^{7}$ No final da década de noventa o acesso à Internet era feito, predominantemente, via linha telefônica. O "cabo" (ou cable) era uma

6 Via linha telefônica.

7 Um cabo significa um canal exclusivo para a conexão do computador à Internet. Ele possui vantagens em relação à linha telefônica por possibilitar o envio e recebimento de maior quantidade de dados de forma mais rápida.

Horizontes Antropológicos, Porto Alegre, ano 10, n. 21, p. 241-271, jan./jun. 2004 
novidade lá por 1998. Hoje em dia ele também se proliferou e divide com a "discada" as formas possíveis de acesso. No início os provedores da capital eram todos pagos. O serviço tinha uma tarifa mensal. $\mathrm{O}$ usuário de Internet tinha um número-limite de horas de acesso. Usando mais se pagava mais. Porém em 1999 surgiu o "paraíso": o acesso gratuito. O primeiro provedor porto-alegrense de acesso gratuito à Internet foi o "Católico". Ele era gerenciado pela Arquidiocese da Igreja Católica em Porto Alegre e tinha a finalidade de oferecer o serviço para o usuário comum e para as instituições filantrópicas. Logo ele desapareceu. Na mesma época surgiu no Brasil o Ig (Internet Gratuita). Esse provedor contemplava várias capitais brasileiras, entre elas Porto Alegre. Ele existe até hoje. Alguns outros provedores gratuitos surgiram. Alguns logo desapareceram. Outros sobrevivem até hoje.

Com aparelhos de computador a preços mais baratos ${ }^{8}$ (ou pelo menos financiados) e a difusão do acesso à Internet, logo a idéia da informática tomou conta dos porto-alegrenses. A cada dia que passava uma nova residência ficava "conectada" à rede. A nova tecnologia era difundida mais rapidamente pelos jovens e cada vez mais eles estavam "navegando" por sites, trocando e-mails e se comunicando em chats. $\mathrm{O}$ encontro virtual em salas de bate-papo virtual (chat) cada vez mais ia seduzindo os jovens da cidade. Pessoas com mais de 25 anos talvez lembrem do momento pré e pós-informática (incluindo aí computadores, Internet, sites e chats). Os mais jovens já entravam na adolescência munidos dessa forma de comunicação e pouco estranhavam as novidades.

E o que acontece quando uma tecnologia difundida em âmbito mundial aporta em Porto Alegre? Bom, durante o século XX várias outras tecnologias chegaram à cidade. Apenas com a intenção de mencionar devemos lembrar que o bonde com tração animal veio a tornar os trajetos mais rápidos. Logo em seguida a eletricidade, e inclusive o bonde elétrico, mudaram ainda mais o ritmo da cidade. Também devemos lembrar de como a telefonia foi se estabelecendo gradualmente na cidade.

Cada uma dessas tecnologias, e ainda poderíamos lembrar de outras, trouxeram a Porto Alegre uma nova representação de tempo e espaço. Assim como acontecia em âmbito mundial, pelo menos no Ocidente, o tempo começou a se tornar uma dimensão cada vez mais descontínua

8 Em relação aos computadores pessoais da década de oitenta e início dos anos noventa, quando o preço era muito alto.

Horizontes Antropológicos, Porto Alegre, ano 10, n. 21, p. 241-271, jan./jun. 2004 
(Featherstone, 1995, p. 21). Em termos de espaço cabe a observação Anthony Giddens (1991) a respeito do "alongamento" da relação entre formas sociais e eventos locais, ao qual o autor se refere como sendo característico de um movimento de globalização. Para ele esse fenômeno pode ser definido como sendo "a intensificação das relações sociais em escala mundial, que ligam localidades distantes de tal maneira que acontecimentos locais são modelados por eventos ocorrendo a muitas milhas de distância e viceversa" (Giddens, 1991, p. 70). Isso significa que podemos pensar da mesma maneira a respeito da inserção do conjunto computador/Internet em solo porto-alegrense.

Pesquisando sobre essa união (Porto Alegre mais computador/Internet) cheguei a um fenômeno que basicamente envolvia interação social e mídia digital. Uma nova tribo, seguido o sentido proposto por Michel Maffesoli (1987), começou a ocupar a cidade no início do século XXI: a turma de chat. São os jovens porto-alegrenses que cultivam a sociabilidade virtual via Internet e organizam suas relações a partir daí. E é justamente aí que o conjunto computador/Internet deixa de ser um espaço onde prevalecem, majoritariamente, heterogeneidade e diversidade, para dar lugar a nichos de sobrevivência de minorias metropolitanas, as quais prezam pela homogeneidade de classe (ou mesmo etária) e estilos de vida.

O conjunto computador/Internet mistura características do telefone, da televisão e do vdeogame e nos lembra dos momentos em que a cidade os recebeu. Cada uma dessas tecnologias teve um momento de inserção na cidade de Porto Alegre. Aliado a cada um deles, a sociedade revelava uma forma de utilização das tecnologias e envolvimento com elas. Em cada um desses momentos uma nova cena tomou a cidade. Atualmente o cenário é de difusão do computador/Internet, das tribos de chat, dos indivíduos conectados e interagindo em forma de rede e revelando peculiaridade desse tipo de envolvimento.

Tornou-se uma experiência comum para quem utiliza computador/ Internet o acesso a uma sala de bate-papo virtual (chat). A primeira experiência com a comunicação via chat de conversação escrita gera caminhos a serem seguidos. O indivíduo ou não gosta e acaba por repudiar, ou se coloca de maneira neutra, ou então segue a utilizar o sistema. Entre esses três níveis existem gradações. Por exemplo, entre os que utilizam o sistema existem os que usam eventualmente e os que utilizam regularmente. Entre 
os que utilizam regularmente existem os que criam laços de amizade mais duradouros e ficam fazendo parte de uma rede social mediada pelo contato do computador e, ainda, os que não se inserem em redes. Estes acabam por estabelecer contatos mais efêmeros e fortuitos.

Pensando a partir de dicotomias podemos pensar sobre a associação entre computador/Internet e Porto Alegre como criando dois mundos. De um lado temos o mundo on-line, que é aquele que medeia a interação entre indivíduos virtualmente a partir da mídia digital. De outro lado temos o offline, que é aquele mundo que medeia a interação entre indivíduos sem o equipamento computador/Internet. Esse caso é quando os indivíduos interagem face a face, diferentemente do outro modo, que é a partir da interface do monitor/computador que coloca os indivíduos em interação via Internet.

Lembrando o leitor da proposta inicial, aqui se propõe a reflexão sobre quando a tecnologia digital do computador/Internet se associa com a cidade de Porto Alegre criando um novo espaço de trocas sociais. Dessa forma, serão consideradas paralelamente as duas formas de interação (on e offline). Contemporaneamente algumas pesquisas dão conta do espaço de interação que se cria com a forma de comunicação on-line. Nesse caso, tratam basicamente de uma desterritorialização em potencial presente na Internet. É quando não importa se um indivíduo está a quilômetros de distância de outro. Importa é que estão cultivando uma interação, independentemente da proximidade geográfica e dependentes do espaço virtual de trocas que se forma.

Esse tipo de espaço também está presente na interação entre indivíduos "próximos", moradores da mesma cidade, por exemplo. No entanto, o diferencial está na associação estreita existente entre as dimensões on e offline. Isso significa que, nesse caso, é importante sim o fato de dois indivíduos, por exemplo, estarem em interação e próximos geograficamente. Ao invés de uma desterritorialização, nesse caso há sim uma territorialização, pelo menos quanto ao que se refere à propensão ao encontro social. É quando o fato de ser, ou não ser, de Porto Alegre influencia na interação virtual efetivada em ambiente de chat. Observando mais especificamente fica clara, inclusive, uma propensão à sociabilidade com indivíduos ainda mais próximos, àqueles que moram em uma determinada zona da cidade. 
No caso pesquisado ${ }^{9}$ foi esse o aspecto que ficou mais claro. Embora a vivência essencialmente on-line tenha vida autônoma, a associação, e daí o termo "estreitamento", da vivência on e off-line foram os aspectos mais claros no tipo de sociabilidade que atualmente se opera via computador/ Internet na cidade de Porto Alegre a partir do chat do provedor Terra Porto Alegre. O que coloca os pesquisadores desse tema diante de um novo contexto, aquele em que se misturam as vivências on-line em chat e offline no contexto urbano da cidade.

\section{0 aspecto visual}

Para pensarmos no conjunto computador/Internet atual precisamos explorar em que bases ele se desenvolve. O que nos leva à interface gráfica. Por interface devemos entender o conjunto de elementos (tanto hardware quanto software) que fazem a mediação do usuário com a informática. A interface utiliza o suporte da mídia digital. Porém, se baseia na idéia da linguagem analógica (do mundo ao redor dos seres humanos, das coisas que os cercam). Em termos de hardware, o principal elemento de suporte da interface é a tela do monitor. Através dele é que o usuário irá interagir com o sistema. Em termos de software, o suporte advém da plataforma visual do sistema operacional do computador.

Há algumas décadas o sistema operacional comum dos computadores pessoais possuía a interface de linha de comando. ${ }^{10}$ A mediação entre usuário e informática se dava pela constante programação do primeiro sobre a segunda. Significa que, por exemplo, o gerenciamento de arquivos no computador se dava pela ordem escrita do usuário. Este digitava, via teclado, um comando escrito e a partir daí o arquivo era aberto, ou apagado, ou transferido de pasta, e assim por diante. Atualmente a interface é visual. Isso significa que não é preciso digitar comandos para as tarefas serem executadas. $\mathrm{O}$ usuário de hoje, via mouse por exemplo, interage com a imagem digital projetada na tela do monitor e, clicando ou arrastando, executa as tarefas normais de gerenciamento de arquivos. Por mais que atualmente possa parecer uma tarefa natural, interagir na imagem do computador,

\footnotetext{
9 Fruto da etnografia citada.

${ }^{10}$ A exemplo do DOS.
} 
a maneira que fazemos hoje, condiciona uma série de questões envolvidas com a percepção humana. A "linha de comando" não deixou de existir, apenas mudou de lugar. Antes o próprio usuário de computador tinha de ser o detentor do conhecimento necessário para interagir com a linha de comando. Agora a linha de comando fica a cargo do programador. Ao usuário é mostrada uma outra camada que possibilita a iteração, que é a visual. As camadas, visual e de linha de comando, se sobrepõem. A interação do usuário (não programador) com a interface do computador se dá pela primeira.

Em uma obra recente, Steven Johnson (2001) nos traz o contexto em que surge a interface gráfica. Ele lembra que Doug Engelbart, em 1968, foi o primeiro a projetar uma interface para relacionar o usuário de computador com a máquina. Analisando tecnicamente, essa relação é complicada. A linguagem de computador é organizada em códigos binários (zero ou um) ou abreviaturas de comandos. Já a linguagem do ser humano se dá em outros termos, a partir da fala, de gestos, da escrita, da comunicação visual, etc. $\mathrm{O}$ invento de Engelbart tratava de conciliar a linguagem digital com a percepção humana (linguagem analógica). Para isso ele partiu da idéia de "mapear bits". Foi a primeira vez que o computador digital começou a revelar "espaços". O usuário poderia ir "lá" ou "cá", procurar arquivos em determinados lugares no computador... e assim por diante. Foi nesse momento que surgiram as primeiras "janelas" na tela do computador.

$\mathrm{O}$ usuário poderia abrir espaços (janelas) que possibilitassem a interação com a máquina e seus arquivos. Porém ainda não era possível sobrepor as janelas. Com Alan Kay (Johnson, 2001) surgiu essa possibilidade. Ele se baseou na idéia das pilhas de papéis. Ora, no seu mundo ao redor o indivíduo pode organizar papéis uns sobre os outros. Os que está utilizando ele coloca sobre os demais. Os menos importantes abaixo... Por que não aplicar essa idéia ao espaço digital? Sobre a inovação trazida por Alan Kay Steven, Johnson faz a seguinte consideração:

Podíamos entrar e sair da paisagem da tela, puxar coisas na nossa direção ou afastá-las. A revolução do mapeamento de bits nos dera uma linguagem visual para a informação, mas as pilhas de papel de Kay sugeriram uma abordagem mais tridimensional, um espaço-tela em que era possível entrar. Toda a idéia do computador como um ambiente do mundo virtual tem origem nessa inovação aparentemente modesta, embora fossem ser necessários muitos anos para que esse legado se tornasse visível. (Johnson, 2001, p. 40). 
A partir de então a interface gráfica do computador foi recebendo inovações. A maioria delas baseadas em metáforas do mundo analógico. Foi tomando forma um sistema operacional que imitasse o mundo ao redor do usuário, sua área de trabalho, sua escrivaninha, seu fichário, sua lixeira... Se a lógica de uma escrivaninha é reproduzida no computador, então quem a utiliza fora do computador vai ter uma facilidade maior de interagir com a máquina. Possivelmente o usuário, assim como faz em sua mesa de trabalho, irá, na tela do computador, colocar algumas coisas de uma lado, outras de outro, empilhar algumas janelas (assim como faz com papéis), etc. Da mesma forma ocorre com a lixeira. A lógica da lixeira, sendo reproduzida na tela do computador, induz o usuário a saber deletar (apagar) arquivos.

O sistema operacional de interface de linha de comando causava um certo distanciamento com o usuário. A interface gráfica trouxe o usuário para perto da tela do computador, fazendo com que ele "mergulhasse" na imagem digital. A partir daí surge na tela do computador um espaço com profundidade. $\mathrm{O}$ usuário tem a percepção de que pode entrar nesse espaço, nesse mundo virtual. Philippe Quéau (1993) defende que atualmente existe a proliferação de "imagens de síntese". O nicho onde elas ocorrem é o mundo informático.

Esse tipo de imagem é diferente do até então produzido pelo registro da luz feito pela fotografia. A imagem a que ele se refere é a binária, de computador. Essa imagem não é do mesmo tipo que a obtida pela fotografia. A "imagem de síntese" a que ele se refere é, antes de tudo, linguagem. O computador/Internet é um meio de comunicação que privilegia o layout e a relação visual com o usuário. A formação de um espaço se dá na imersão nas imagens que se sucedem na tela do computador. É aí que o meio de comunicação atinge o status de lugar, de ciberespaço. Há a possibilidade de "mergulho" nessas imagens disponibilizadas virtualmente. Entendo que seja nesse movimento que a simulação produzida na interface gráfica adquire um poder de envolvimento do usuário do computador/Internet. Vamos pensar nas salas de bate-papo virtual (chat).

Chat

O chat é um sistema de comunicação com especificidades e lógica própria. Ele simula o ato de se estar em uma sala com outras pessoas. Os criadores da interface gráfica enfrentavam um dilema: ou tornavam os softwares amigáveis e reproduziam tudo do mundo real (até os defeitos e 
problemas) ou criavam uma mistura entre algo que "lembrasse" o mundo analógico, mas que na plataforma digital tivesse uma lógica própria, que expandisse a funcionalidade. A partir daí podemos pensar a respeito dos chats de Internet e como eles simulam a sociabilidade "real".

O ambiente de chat é formado pela página de Internet que possibilita a interação entre os usuários do sistema. Essa página é composta geralmente por duas partes básicas: uma "listagem" das mensagens compartilhadas entre os diversos freqüentadores do chat naquele instante ${ }^{11}$ e um "formulário" de envio de mensagem escrita. Na listagem aparecem emissor e receptor da mensagem. O resultado é a composição de um texto coletivo no formato de diálogos. Por exemplo:

Anjinho_puc fala com G@t@: legal vc's sempre fazem esses encontros?G@t@ fala com $\S^{\circ}$ ANJO AQUARIANO$\S^{\text {TM: }}$ e aí... me achou mto feia?? (seja sincero!!)

$\S^{\circ}$ ANJO AQUARIANO${ }^{\mathrm{TM}}$ fala com G@t@: Ai guria tu é gatinhaaaa

vocalista louco ICQ: onde é esses encontros ???

G@t@fala com Anjinho_puc: foi a primeira vez q eu fui em um encontro!

vocalista louco ICQ: gostaria de participar...

G@t@ fala com Anjo[ĐM]C: vc nem falou direito comigo lah no encontro!:o(

O formulário geralmente é composto por: a) um campo de preenchimento da mensagem escrita que será enviada; b) o destinatário (escolhido em uma lista que apresenta os usuários do chat naquele instante - quem está conectado); c) o modo de envio (se "aberta"-visualização pública ou "reservada" - visualização exclusiva do emissor e receptor); e d) mecanismos performáticos digitais padronizados ${ }^{12}$ que serão enviados agregados à mensagem escrita. A imagem a seguir nos esclarece sobre a interface do chat:

\footnotetext{
${ }^{11} \mathrm{Na}$ listagem somente podemos ver as mensagens enviadas no "modo aberto" por outros freqüentadores, ou as trocadas entre mim e outro freqüentador no "modo reservado".

12 Imagens de expressões faciais estilizadas, sons e indicação de ações - "fala", "grita", "sussurra", etc.
} 


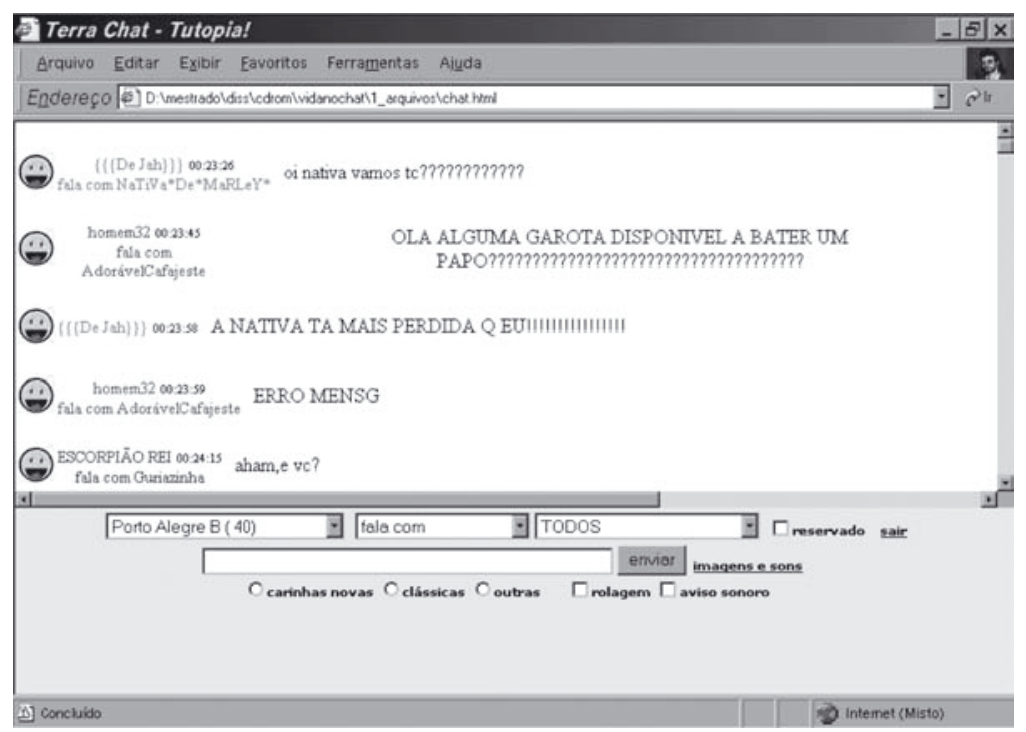

Figura 1

Existem outras modalidades de layout de chat. Cada criador de chat (geralmente um provedor de Internet) tenta produzir um ambiente ao mesmo tempo funcional e agradável ao usuário. Porém é recorrente a utilização do formulário na base da tela. Os dois espaços (listagem e formulário) não se misturam. A sua disposição lembra a tentativa de Elgelbart e os primórdios das "janelas" digitais projetadas na tela do computador.

\section{Sociabilidade via Internet}

No chat a comunicação é dinâmica e lembra a conversação. A troca de mensagens ocorre rapidamente entre emissores e receptores, o que se chama de "tempo real", ou melhor, sincronia. A troca de mensagens via $e$ mail, por exemplo, também pode ocorrer em tempo real. Nesse caso é preciso que alguém envie uma mensagem e alguém, imediatamente, receba e leia essa mensagem. No entanto, o costume aliado à modalidade do e-mail é de se utilizar a assincronia. Isso significa que a mensagem é enviada de um emissor a um receptor. Porém esse só irá tomar conhecimento da mensagem em algum momento oportuno, talvez no mesmo dia do envio, 
talvez em outro dia, e assim por diante. A comunicação via Internet pode variar entre os modos sincrônico e assincrônico. Cada caso possui certas especificidades e propicia um tipo de envolvimento social.

No caso do chat, quando a comunicação é sincrônica, há a possibilidade de um tipo de envolvimento semelhante à sociabilidade. Digo semelhante porque não é do tipo clássico proposto, por exemplo, por Georg Simmel (1996)e Alfred Schutz (1979). A sociabilidade via Internet compartilha de alguns pontos dessas teorias, porém possui especificidades que devem ser respeitadas e nos propõem cunhar um novo conceito, o de "sociabilidade virtual". As características desse tipo de envolvimento social são resultantes da principal característica do meio em que a troca comunicativa ocorre: no meio virtual, via on-line.

Para Georg Simmel os indivíduos sempre procuram formar uma unidade - sociedade - de acordo com seus impulsos. Esses impulsos formam o conteúdo. Essa matéria ainda não é social. Somente é quando toma a forma de uma sociação pela qual os indivíduos satisfazem seus interesses. Ele argumenta que: "Esses interesses, quer sejam sensuais, ou ideais, temporários ou duradouros, conscientes ou inconscientes, causais ou teleológicos, formam a base das sociedades humanas" (Simmel, 1996, p. 166).

Segundo o autor, na sociabilidade há a reviravolta entre o conteúdo gerador do encontro e a forma dele transcorrer. A forma passa a determinar o conteúdo e torna-se um valor supremo. A sociedade, que significa uma agregação de indivíduos em embate uns com os outros, gera os conteúdos ou interesses materiais ou individuais. Por exemplo, os interesses econômicos fazem com que os indivíduos se agreguem em associações, irmandades, etc. Mas também está presente um impulso de agregação (forma). Ele pode, às vezes, sugerir os conteúdos concretos da associação. A sociabilidade também está além das realidades objetivas da vida real. Ela é um "impulso" (forma) e não está atrelada nem condicionada a motivações concretas (conteúdo, matéria): "Isso nos dá uma imagem abstrata, na qual todos os conteúdos se dissolvem no mero jogo da forma" (Simmel, 1996, p. 169).

Para Alfred Schutz (1979) as pessoas agem em função de experiências da vida cotidiana. Mesmo havendo uma multiplicidade de "mundos" e "realidades", são pessoas que buscam experiências significativamente comuns no envolvimento do "nós" (face a face). O envolvimento está sempre como uma possibilidade objetiva, sempre atrelado a um desejo de intersubjetividade. 
A partir do presente vivido um indivíduo percebe o seu semelhante, o outro. A interação social pressupõe a existência de uma simultaneidade vivida. Essa simultaneidade abrange tanto a percepção do outro enquanto pessoa, como a percepção de seu pensamento. Existe um deslocamento no tempo compartilhado, ao que Alfred Schutz se refere como sendo um "envelhecermos juntos". Isso significa que, da mesma forma que experimento a consciência do outro no presente vivido, ele experimenta a minha consciência.

A sociabilidade está condicionada à atos comunicativos entre um "eu" que se volta aos outros e os apreende como pessoas. Esse processo se dá a partir da percepção do outro enquanto um corpo no espaço que compartilha comigo um ambiente comunicativo comum. "O ambiente comum de comunicação pressupõe que a mesma coisa que me é dada 'agora' (mais precisamente, num 'agora' intersubjetivo), com um determinado colorido, pode ser dada a Outro do mesmo modo, 'depois', no fluxo do tempo intersubjetivo, e vice-versa" (Schutz, 1979, p. 161-162).

Em ambiente de chat é visível a relação simmeliana entre conteúdo e forma. Os usuários de chat começam a utilizar o sistema interessados em diversos assuntos. Entre eles, prevalecem o combate ao sentimento de solidão $0^{13}$ e a busca por participar de uma coletividade, assim como a busca por envolvimentos amorosos. Durante a comunicação com outros usuários criamse um conjunto de estratégias que articulam diversos assuntos para sustentar a interação. Nesse momento percebe-se a redução da presença da variável conteúdo e aumento da forma. Não importa sobre o que se irá bater papo. $\mathrm{O}$ importante é estar interconectado e trocando mensagens. Podemos observar essa substituição de centro de importância quando verificamos que os assuntos tratados no momento de interação via chat são efêmeros e fortuitos.

O que permanece inalterado é o desejo de trocar mensagens, de estar ligado com algum outro usuário por um canal de comunicação. Isso ocorre tanto para aquele freqüentador eventual quando para o regular, que está inserido em uma rede de relações mais duradoura. No caso do interesse de se envolver amorosamente, esse acaba ficando em segundo plano em relação ao convívio com os demais usuários. Os indivíduos acessam o chat e ficam ali, trocando mensagens, batendo papo. Tudo parece, até certo ponto, despretensioso, mas está latente o desejo de "ficar" ou "namorar". ${ }^{14}$ Entre-

${ }^{13}$ Uma reflexão sobre "solidão" está em Carvalho (1995).

${ }^{14}$ Etnografias que tratam a respeito desses conceitos são encontradas em Rieth (2000) e Schuch (1998).

Horizontes Antropológicos, Porto Alegre, ano 10, n. 21, p. 241-271, jan./jun. 2004 
tanto, para não estar sozinho é preciso que o freqüentador entre no jogo que existe na convivência em ambiente de chat e apreenda suas regras e estratégias.

Em relação a elas, as principais que se manifestam são o tipo de linguagem e a alternância entre mostrar e esconder. Sobre a linguagem cabe colocar que ela privilegia a iconografia, que é quando uma palavra agrega tanto a dimensão visual quanto sonora. A potencialidade fonética da comunicação oral fica manifestada na comunicação escrita em ambiente de chat. Da mesma forma que a visual. Ou seja, a comunicação no chat se dá via significados emitidos na maneira de redigir uma palavra ou oração. Para isso são utilizados recursos, principalmente o código alfa numérico. Sobre a estratégia de conduta em chat me refiro ao jogo que se dá no jogo entre os modos "aberto" e "reservado" de comunicação.

Teclar"15 "no aberto" ou "no reservado" indica a disposição da pessoa. Manter um canal comunicativo no modo aberto significa estar aberto à participação de outros freqüentadores, mesmo que isso não seja aceito com tanta facilidade na prática. Caso alguém tente se intrometer na conversa de dois freqüentadores de chat, o resultado pode ser inútil, ele pode ser ignorado. A abertura está mais indicada a quem pertence à rede que se forma na interação. Alguém que converse no "aberto" indica com quem se relaciona. Mostra a proximidade com algum outro freqüentador e mostra em qual rede participa. Nesse caso torna a conversa pública, assim como o laço de amizade.

Entre freqüentadores que não estão inseridos em uma rede de relações é mais comum a utilização do modo reservado. A busca por envolvimentos amorosos está bastante presente e é feita, nesse caso, por um canal de comunicação discreto. Talvez porque evitam divulgar o teor da conversa para os demais presentes na sala. Utilizar o modo reservado pode ser também um simples desejo de manter a conversa livre da interferência de demais freqüentadores, mesmo que ela não tenha um teor de envolvimento amoroso.

${ }^{15} \mathrm{O}$ mesmo que conversar. "Teclar" é o termo utilizado para significar as trocas comunicativas via Internet, quando a utilização do periférico "teclado" é fundamental. O termo abarca, de certo modo, todas as dimensões comunicativas operacionalizadas virtualmente e que, fazendo um paralelo, pode ser utilizado como sinônimo de "conversar". 
O que se pode afirmar é que a escolha pela divulgação ou não da comunicação é apropriada simbolicamente pelos freqüentadores do chat. Essa escolha também comunica sobre a disposição do indivíduo em ambiente de chat. Mesmo que se escolha o modo reservado pela discrição, poderá haver a interpretação de ser uma aproximação amorosa. A opção pelo modo aberto ou reservado também passa pela comunicação trocada na performance em ambiente virtual. Geralmente é possível observar quem está teclando no "reservado" quando alguém responde, no modo aberto, a uma pergunta que não é possível observar na lista de mensagens enviadas e recebidas (na listagem). É sinal que a pergunta foi feita no modo reservado, mas a resposta foi feita no modo aberto. A comunicação aberta ou reservada pode significar várias disposições, assim como as piscadelas de Geertz (Geertz, 1989, p. 16).

Enquanto interagem no chat os usuários do sistema percebem outros usuários e compartilham um mesmo tempo transcorrido e um mesmo espaço de convivência. Alfred Schutz (1979) trata da percepção do outro enquanto um corpo no ambiente. Em ambiente de chat não estão presentes os corpos dos humanos. Além disso, o conceito de ambiente é diferente daquele proposto por ele. A percepção do outro se dá pela percepção de um usuário utilizando um nick ${ }^{16}$ e trocando mensagens. O nick atinge o status de signo e já começa a expor os "motivos afim de". ${ }^{17}$ Embora vários usuários acessem o chat ao mesmo tempo, a percepção do "nós" ocorre quando há a criação de um canal de comunicação entre emissor e receptor da mensagem.

O ambiente compartilhado passa a ser o da plataforma do chat, que se materializa no layout que é visualizado pelo monitor do computador. Não há um contato face a face. Ao invés disso temos uma relação "face a tela" que é intermediada via uma interface visual de relacionamento. No chat não há o contato schutziano de troca de olhares, de sutileza e percepção do outro freqüentador. Ao invés disso, há a criação de um espaço com alto grau de interpretação, já que estão anuladas as percepções sensoriais humanas. A interpretação gera o descobrimento do outro. Falta a visão do corpo do outro, falta ouvir o outro, falta sentir o toque do outro e falta cheirar o outro.

\footnotetext{
${ }^{16}$ Abreviatura de nickname, que significa "apelido". O nick é a denominação que os internautas fazem ao apelido que se utiliza na Internet. Adiante será apresentada uma reflexão sobre o nick. Embora seja de origem inglesa, essa palavra já se incorporou como gíria de internautas.

${ }_{17}$ Segundo Alfred Schutz (1979), na interação social, no encontro face a face, os indivíduos já vão identificando os motivos afim de e por que dos outros.
}

Horizontes Antropológicos, Porto Alegre, ano 10, n. 21, p. 241-271, jan./jun. 2004 
Todas essas faltas criam a busca da descoberta do outro. Se na sociabilidade de Alfred Schutz (1979), do contato face a face, essa "descoberta" está presente, está ainda mais na sociabilidade face a tela com falta de utilização dos sentidos corporais. Essa descoberta se dá simultaneamente. Os freqüentadores de chat compartilham de um mesmo tempo transcorrido, o que aproxima a idéia de existir um "presente vivido" e um "envelhecer juntos".

Esses dois pontos da teoria schutziana somente são possíveis na sociabilidade em ambiente de chat porque há, nessa convivência, sincronia das mensagens enviadas. Não é o caso da comunicação por correio eletrônico. A comunicação feita pela troca de mensagens via e-mail não propicia o fenômeno de sociabilidade virtual. Na comunicação por e-mail (e outros sistemas semelhantes) não há a geração de simultaneidade. Nesse caso há assincronia. Também não é o caso das "listas de discussão", que são intermediadas por e-mail.

Por sociabilidade virtual devemos entender a interação social realizada pela comunicação sincrônica e com contato interpessoal mediado pela tela do computador. Ela apresenta a mesma inversão entre forma e conteúdo apresentada por Georg Simmel (1996). O conteúdo de interesses que gera a aproximação com outras pessoas dá lugar ao prazer de se estar associado via imagem digital. No caso do chat parece haver um processo de adequação da técnica em favor da estratégia humana de estar acompanhado (não estar só, interagir e socializar).

A sincronia é a mesma da comunicação oral, com curto espaço de tempo na troca de mensagens. Enquanto o emissor envia a mensagem o receptor já a está decodificando, com uma diferença de tempo de segundos. Existe um presente compartilhado. Em sincronia uma pessoa testemunha a presença da outra no seu mesmo tempo. Existe um imediatismo temporal, da mesma forma que há um espacial (aquele da imagem com profundidade projetada na tela do computador). Entretanto, nesse caso o espaço que rodeia uma pessoa não é o mesmo que rodeia a outra. $\mathrm{O}$ que há de igual é a tela do computador por onde se visualiza o ciberespaço.

O ciberespaço ${ }^{18}$ é composto por certas características que o elevam de simples meio de comunicação à espaço compartilhado. Nesse sentido, talvez

\footnotetext{
${ }^{18}$ Aqui o termo se refere à dimensão formada pela interconexão de milhares de computadores/ Internet ao redor do mundo. O fluxo constante de informação entre esses pontos da rede eleva o sistema de simples meio de comunicação à espaço de compartilhamento de dados e, inclusive, de vivência e interação sociais.
}

Horizontes Antropológicos, Porto Alegre, ano 10, n. 21, p. 241-271, jan./jun. 2004 
a característica principal seja a de "deslocamento". O internauta percebe a Internet e seu conjunto de sítios (sites) como sendo um campo aberto ao trânsito. Ele pode estar em sua residência, na frente de seu computador, ao mesmo tempo em que freqüenta a biblioteca da universidade ou então o grupo de amigos no chat que se encontra regularmente em tal sala de batepapo. O que há realmente é um constante "fluxo".

A existência de uma rede organizada com constante troca de informação cria um espaço simbólico de trocas. Manuel Castells (1998, p. 408) entende que com a Internet "as localidades se desprendem de seu significado cultural, histórico e geográfico, e se reintegram em redes funcionais ou em colagens de imagens, provocando um espaço de fluxo que substitui o espaço de lugares". Por "espaço de fluxo" o autor entende que seja um espaço formado entre a origem e o destino da comunicação em rede. Sendo assim, existe uma comunicação, por exemplo, maciça entre uma cidade A e outra B. Nesse canal de comunicação há um espaço de fluxo.

\section{0 envolvimento}

Quando o conjunto computador/Internet começou a proliferar em Porto Alegre várias rotinas começaram a ser alteradas. Era mais fácil, por exemplo, enviar e receber arquivos digitalmente via e-mail. E essa transformação, embora hoje pareça naturalizada, foi extremamente significativa. No mundo empresarial a presença dessa tecnologia facilitou a comunicação e a troca de informações. Um orçamento de produtos e serviços, por exemplo, que antes era no máximo enviado via fax, com a Internet era enviado via e-mail. Com isso o tempo para realizar essa tarefa foi reduzido. Não era mais preciso imprimir e passar o orçamento no aparelho de fax. Com a Internet o envio era digital e imediato. Além disso, o receptor da mensagem poderia ser múltiplo. Um emissor, com uma única ação (envio de e-mail), poderia se comunicar (enviar uma mensagem publicitária, por exemplo) com várias outras pessoas.

Não faltariam exemplos de como o computador/Internet foi sendo utilizado. Em cada segmento surgiu uma nova maneira de utilizá-lo. Na esfera acadêmica essa tecnologia facilitou a obtenção de informações. Bibliotecas, publicações e autores do mundo todo podem ser contatados rapidamente via Internet. As tarefas de pesquisa se tornaram relativamente mais fáceis e 
rápidas. A relação entre colegas e entre professores e alunos também se modificou. Via e-mail ou site eles podem rapidamente trocar informações sobre aulas, cursos, congressos e palestras. O que coloca uma outra condição: ficou cada vez mais difícil participar do mundo sem um computador/ Internet.

Uma experiência que começou a se tornar cada vez mais comum foi a interação virtual em ambiente de chat de Internet. Como acontece de uma pessoa virar freqüentadora de sala de bate-papo? Em um primeiro olhar parece que estão fortemente presentes o combate ao sentimento de solidão e a busca por relacionamentos amorosos. Porém, não podemos negligenciar que antes das motivações individuais existem condições sociais propícias. Existe um momento e as condutas individuais são fruto desse panorama. O surgimento do freqüentador de chat faz parte do processo de "novo tribalismo" (Maffesoli, 1987).

A familiarização com as máquinas, incluindo aí televisão, telefone e computador, faz com que seja algo natural conviver em ambientes virtuais. Existe uma base, tanto tecnológica quanto cultural, que suporta o cultivo da sociabilidade em ambientes virtuais. Há cerca de cinco anos esse fenômeno ainda causava certo estranhamento. De lá para cá cada vez mais ele tornouse banal, comum, diário e cotidiano. Essa absorção é mais evidente entre as gerações jovens e de classe média. Nelas a prática da sociabilidade virtual mistura-se à vida cotidiana.

A interação social via chat disponibiliza algumas facilidades para os indivíduos. A principal delas é o conforto de poder estar em casa conectado ao computador e poder conversar com outras pessoas, interagir com a turma de amigos, fazer novas amizades, namorar, etc. Diante de um controle do anonimato, as manifestações individuais são potencializadas em ambiente de chat (Jungblut, 2000). Alguns freqüentadores ficam fascinados por essas características. Além disso, devemos ter claro que o ambiente de chat adquire o status de mais um outro ponto de encontro na cidade de Porto Alegre.

Independentemente de estar no ciberespaço, o chat se transforma em um local onde um segmento de pessoas passa alguma parte do tempo do dia. Esse segmento possui um perfil específico. Talvez fosse melhor tratar de "perfis", ao invés de um perfil. Quando o computador/Internet começou a se difundir na cidade de Porto Alegre o perfil do usuário era mais homogê- 
neo. Quase dez anos atrás prevalecia um tipo de usuário jovem, com alto poder aquisitivo e do sexo masculino. Hoje em dia esse perfil tornou-se mais heterogêneo. Embora ainda seja muito difundido entre os jovens (entre 20 e 30 anos), o segmento com mais idade também se tornou um grande utilizador de computador/Internet e chat.

A associação entre chat e perfil do usuário é um fator de grande importância. Dependendo do estilo de vida do indivíduo haverá um tipo específico de envolvimento com essa tecnologia. Vamos pensar a partir de alguns exemplos. O usuário adolescente, que geralmente acessa a Internet de sua residência, provavelmente estará presente na sala de bate-papo em um determinado horário. Provavelmente será em um horário diferente daquele da escola. O horário de acesso também será resultante do tipo de conexão que ele utiliza, se discada ou via cabo. No primeiro tipo se utiliza a linha telefônica. Paga-se o equivalente a uma chamada local. Acessar a Internet em horário comercial, durante uma hora por exemplo, é muito mais dispendioso do que acessar o mesmo tempo durante a noite. Para esse perfil de usuário é comum freqüentar o chat durante a noite, quando são oferecidos pelas empresas de telefonia descontos no preço da chamada.

A tecnologia do cabo ainda é um tanto dispendiosa. Atualmente existem várias alternativas no mercado. Há algum tempo o cabo ainda era raro e caro. Atualmente, embora ainda um tanto dispendioso, tornou-se mais popular e compete paralelamente com conexão discada. A principal vantagem do cabo está nele propiciar uma conexão exclusiva a Internet (não utiliza a linha telefônica), com maior qualidade no envio e recebimento de dados (maior quantidade e velocidade) e a um preço único. Nesse caso, independentemente do acesso ser em horário comercial ou não, paga-se um preço único ao final do mês. Essa tecnologia tornou-se mais popular, primeiramente, no setor empresarial. Porém logo foi disponibilizada a preços mais acessíveis e incorporada ao uso domiciliar. Um usuário que possua essa tecnologia irá acessar o chat de forma mais independente do horário, tanto em horário comercial quanto à noite.

Também existe o usuário de chat que o acessa de seu local de trabalho. É aquele indivíduo que está trabalhando e todo o tempo conectado. ${ }^{19} \mathrm{Se}$ ele não possuir computador em sua residência, então irá acessar a Internet somente no horário comercial. Dependendo dessas variáveis, principalmente

19 Geralmente utilizando uma conexão via cabo. 
local de acesso e tipo de conexão, haverá a interação em ambiente de chat de pessoas com perfis semelhantes e em determinados horários específicos. Os "trabalhadores" geralmente acessam do local de trabalho, durante o horário comercial. Os "estudantes" geralmente acessam durante a noite, de suas residências, e assim por diante. Não existe algum tipo de regra em relação a essas associações. Cabe apenas pensar que existe uma forte e inegável relação entre o perfil off-line do internauta e a condição para estar conectado, on-line, no ciberespaço, passível de ser encontrado por outros internautas... ou em ambiente de chat ou em outra forma.

\section{A forma}

Quando começam a freqüentar o chat os internautas acabam criando laços na forma de rede. Existem os casos em que a pessoa acessa eventualmente o chat e os casos em que o acesso é regular. Nos dois tipos de conduta há a formação de rede. Entre freqüentadores regulares a rede é mais estabelecida e se reproduz diariamente, com pouca variação. Os freqüentadores eventuais criam laços pouco estabelecidos, mesmo assim a cada acesso criam laços com demais internautas, que estão regularmente ou eventualmente na sala.

"Rede" é um conceito adequado para tratar da organização social em meio urbano. J. Barnes (1987) utiliza a "rede social" como um recurso analítico capaz de dar conta de processos sociais onde a conexão não se dá via limites de grupos e categorias. Isso ajuda a identificar quem são os líderes e quem são os seguidores. As redes sociais são um sistema analítico mais frutífero em sociedades contemporâneas e complexas. Em sociedades tradicionais há falta de direção na transmissão da informação. Os gráficos a seguir ilustram essas situações:

Nesse caso, "Anjo", "Juliana Q" e "Escorpião Rei" mantêm um contato quase diário na sala "Porto Alegre A". "Aprendiz de Cafajeste", "Teddy", "Isa" e "Ani" compartilham da mesma situação, porém utilizam a sala "Porto Alegre B". São freqüentadores regulares. Cada um também estabelece vínculos com demais pessoas do chat. "Juliana Q" está regularmente na sala, porém também acaba mantendo contato com outras pessoas. "Escorpião Rei" costuma entrar na "Porto Alegre A" e na "Porto Alegre B", mantendo vínculos com pessoas dos dois ambientes. 
Nesse outro exemplo temos a rede ampliada. Estamos agora considerando os demais freqüentadores do chat: os eventuais. Eles acabam se inserindo na rede. Esse é o caso de "Ju_psicoPuc". Nesse dia "Juliana Q" estava mantendo contatos na sala "Porto Alegre B".

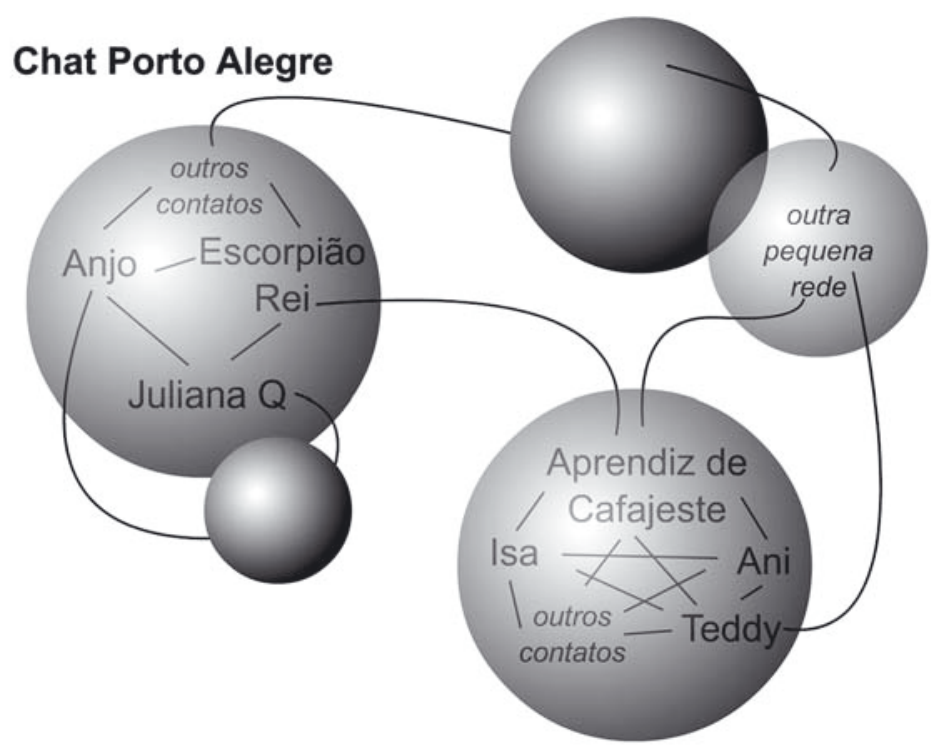

Figura 2. Rede estabelecida entre freqüentadores regulares do chat. 0 convívio quase diário gera pequenas redes de sociabilidade que estão ligadas através de seus membros. Com o passar do tempo acabam surgindo as turmas, por exemplo, da Porto Alegre $A$ e da POA B.

Todo o dia a disposição gráfica da rede se modifica. Porém os laços entre freqüentadores regulares tendem a se repetir. São acrescentados os laços dos freqüentadores eventuais. De qualquer forma, os laços podem acabar sendo criados entre os vários tipos de freqüentadores. O surgimento do freqüentador de chat está estreitamente ligado à sua inserção em uma rede. É quando ele começa a conhecer melhor outras pessoas, troca confidências, cria amizades, conversa e experimenta o sentimento de grupo, de turma... 


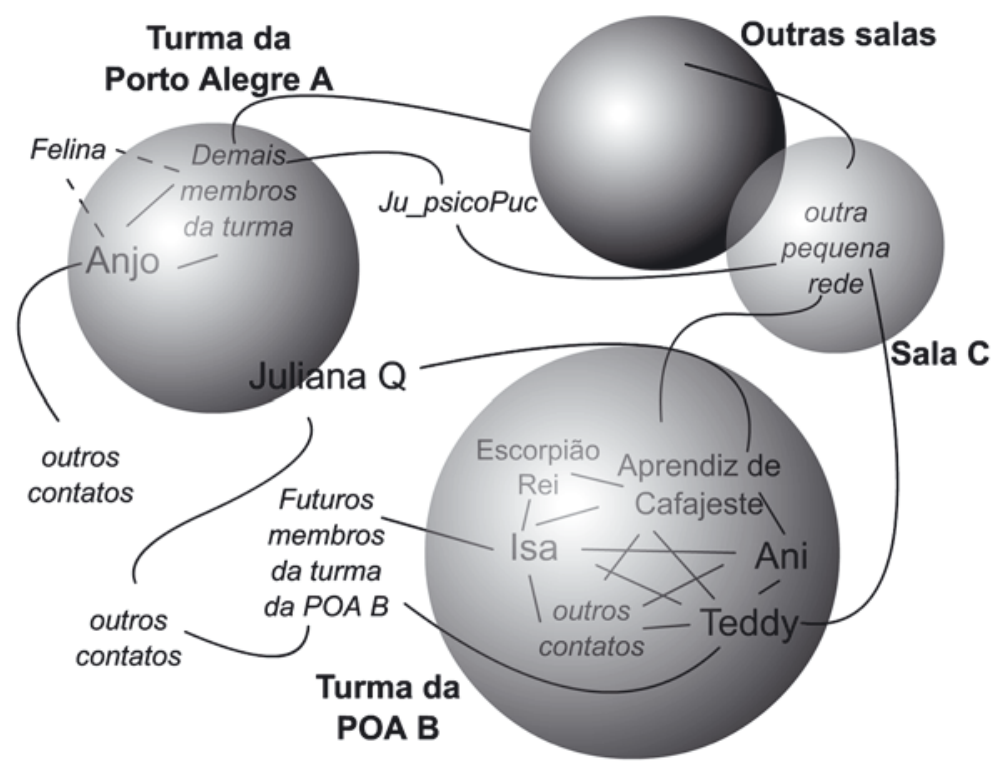

Figura 3. Rede estabelecida entre freqüentadores regulares e eventuais do chat. Mais claramente delimitadas, as redes vão sofrendo alterações. Novos contatos surgem, antigos são desteitos, alguns membros migram, e assim por diante...

\section{Os interesses}

A apropriação e movimentação no espaço social criado em ambiente de chat se dá em decorrência de um perfil específico. A turma da "Porto Alegre B" do provedor Terra tem um perfil. Ele é diferente daquele da turma da "Porto Alegre A". Esse era diferente ainda do pessoal da Conex. ${ }^{20}$ Em outros chats existem turmas com características também diferentes. Ainda no período de definição do grupo que seria pesquisado fiz contato com a turma do chat do provedor Terra "procura 30-40". Eram pessoas com mais idade. Outro tipo de poder aquisitivo, outras aspirações na

\footnotetext{
${ }^{20}$ Provedor de acesso que estava instalado no Rio Grande do Sul e encerrou suas atividades em 2000.
} 
vida e outra relação com o chat. Uma turma de chat cultiva hábitos comuns que garantem a ela a coesão necessária para atingir o status de "grupo". As características básicas que propiciam o encontro no chat são horário e dia da semana que costuma acessar. No entanto, devemos lembrar que essas duas variáveis são ainda resultantes da combinação entre as acumulações de capitais econômico e cultural do indivíduo.

$\mathrm{Na}$ Conex havia "os do dia" e "os da noite". Na sala "Porto Alegre A" o contato foi feito mais freqüentemente no período da noite. Quem acessava naquele momento era um tipo de usuário. Eles geralmente acessavam de casa, eram estudantes, adolescentes e ainda sustentados pelos pais. Suas estratégias na relação com o chat giravam em torno de interesses desse segmento. A turma da sala "Porto Alegre B" tinha um perfil. Os membros dessa rede possuíam um estilo de vida que garantia a eles compartilhar o mesmo espaço virtual de chat, no mesmo momento. A partir daí existe uma condição para a aproximação, o cultivo da sociabilidade e o surgimento de uma "turma".

No caso da rede estabelecida na sala "Porto Alegre B", a maioria dos seus membros acessava a Internet do local de trabalho. O momento para o cultivo da sociabilidade virtual era durante o horário comercial. Para eles essa "quebra" das atividades profissionais representava uma descontração e desconcentração momentâneas. Além disso, servia para preencher um sentimento de que muitas vezes se queixavam: a falta de sociabilidade lúdica entre os colegas de trabalho.

As dificuldades de uma interação lúdica mais intensa era o argumento sobretudo usado por trabalhadores que recentemente se deslocaram para fixar residência na capital, provindos de cidades interioranas. Um dos membros da rede da "Porto Alegre B", "Teddy", havia há pouco saído de cidade natal (Erechim) para estudar em Porto Alegre. E, ainda, tanto ele quanto "Isa", outro membro da rede, compartilhavam de um mesmo panorama do atual mercado de trabalho. No ambiente de trabalho deles havia uma certa ausência de colegas. A esse fenômeno se somava o do próprio processo de trabalho atual (reengenharia), pela redução dos postos de trabalho e busca da "qualidade total". Isso significa que o empregado que antes fazia certas funções agora desempenha tarefas de cargos extintos. Nesses casos não existe uma "turma" do serviço que compartilha momentos de sociabilidade lúdica. 
Para essa rede etnografada, o lazer cotidiano consistia em acessar o chat do provedor Terra, sala "Porto Alegre B", no horário comercial. Era possível ver quase todos os membros diariamente interagindo. Dos seus locais de trabalho que utilizam a conexão via cabo, os entrevistados dizem ficar o tempo todo conectados na Internet. Isso lhes possibilita pequenos tempos-instantes de "fuga" das atividades profissionais, entrar no chat e ir conversar com os amigos virtuais. Alguns faziam isso várias vezes ao dia, outros apenas algumas vezes. De qualquer forma, acessar o chat e manter a comunicação diária com a rede significava para eles pertencer a uma turma que, nesse caso, possuía inclusive denominação: POA B.

Dessa forma eles criavam para si um "pedaço" de trocas sociais, no sentido proposto por José Magnani (1984, 2000). O que nos possibilita tratar como sendo o "pedaço da POA B". No pedaço há uma preeminência das relações sociais e dos códigos e símbolos comuns. Mudando-se o ponto no espaço, o "pedaço", conceito cunhado por José Magnani, é levado junto. A "mancha" (tempo-espaço) é fixa na paisagem (Magnani, 1984). Ela oferece um conjunto de práticas que envolve os seus usuários (por exemplo, o caso do lazer). Ela é um ponto de referência físico. Os dois não são isolados. As pessoas transitam entre eles. Os caminhos não são aleatórios. Existem trajetos que ligam pontos dentro da mancha. Através deles o pedaço é aberto ao âmbito público, gerando um circuito (Magnani; Torres, 2000).

Além de cultivar momentos de sociabilidade virtual, entrar no chat também possibilitava acessar momentos de sociabilidade face a face em determinadas "manchas" da cidade. Era quando a turma combinava um "encontro" de seus membros em algum local da cidade. Geralmente o local era escolhido a partir das opções de lazer e boemia que são disponibilizadas atualmente na cidade. A escolha seguia o próprio perfil da turma: membro jovens, com idade média de 22 anos, trabalhadores com médio poder aquisitivo e média escolaridade. Na cidade de Porto Alegre existem locais, incluindo aí bares e casa noturnas, destinados a tipos de público diferenciados. A POA B, por possuir um perfil homogêneo e a partir de um capital cultural e econômico específico, ${ }^{21}$ tratava de "consumir" locais da cidade de acordo com essas variáveis. Dessa forma, costumavam organizar encontros da turma nos circuitos caracteristicamente boêmios da "Lima e Silva" e da "Goethe".22

${ }^{21}$ No sentido proposto por Pierre Bourdieu (1989).

22 "Lima e Silva" em decorrência da estrutura que se forma: uma concentração de bares e casas noturnas principalmente na rua General Lima e Silva, no bairro Cidade Baixa, de Porto Alegre, e suas imediações. Da mesma forma que na avenida Goethe, no bairro Rio Branco.

Horizontes Antropológicos, Porto Alegre, ano 10, n. 21, p. 241-271, jan./jun. 2004 
Não era o que acontecia, por exemplo, com a turma do chat "procura 30-40 anos". Nesse caso a rede também organizava "encontros" face a face em determinados locais da cidade. No entanto eram outros locais, destinados a um público dessa faixa específica de idade e com poder aquisitivo mais elevado.

Pertencer à POA B também significava participar de uma boemia porto-alegrense. Nesse caso considerando explicitamente as vantagens da sociabilidade face a face, em detrimento da virtual, que opera quase como uma ferramenta de aproximação. Alguns membros da rede residiam na região metropolitana de Porto Alegre. Embora o provedor Terra disponibilizasse chats sob o título de suas cidades, alguns usuários preferiam interagir na sala intitulada "Porto Alegre". Havia um desejo justamente nesse tipo de convívio. Na Internet existem vários tipos de chat, sob diversos rótulos: cinema, teatro, música, sexo, profissões, religiões, etc. Cada um deles propõe associar usuários com interesses semelhantes. Se, por exemplo, acesso o chat "cinema", significa que lá poderei conversar com alguém que também goste de cinema, independentemente de nossa interação tratar desse conteúdo. Nesse caso prevalece a forma do contato (Simmel, 1996). $\mathrm{O}$ que nos remete ao caso de Porto Alegre e de como a sociabilidade pode ser busca a partir da identificação de pertencimento a ethos e estilos de vida da cidade.

O caso estudado nos faz refletir sobre o encontro do sentimento de comunidade diante da forte globalização. Para Manuel Castells (1999) a comunidade nunca deixa de existir, mesmo com o movimento de urbanização das grandes cidades. Para o autor, as redes sociais existem em todos os contextos, mesmo na cidade e no subúrbio. Nesses casos o que ocorre é a interseção de identidades locais com outras fontes de significado e reconhecimento local. Cabe aqui citar as próprias palavras do autor:

O provável argumento dos autores comunitaristas, coerente com a minha própria observação intercultural, é que as pessoas resistem ao processo de individualização e atomização, tendendo a grupar-se em organizações comunitárias que, ao longo do tempo, geram um sentimento de pertença e, em última análise, em muitos casos, uma identidade cultural, comunal. Apresento a hipótese de que, para que isso aconteça, faz-se necessário um processo de mobilização social, isto é, 
as pessoas precisam participar de movimentos urbanos (não exatamente revolucionários), pelos quais são revelados e defendidos interesses em comum, e a vida é, de algum modo, compartilhada, e um novo significado pode ser produzido. (Castells, 1999, p. 79).

A partir desse ponto de vista podemos pensar em ser a sociabilidade virtual cultivada via Internet um tipo de movimento urbano que leva à formação de comunidades. Elas podem sobreviver independentemente de serem ligadas exclusivamente à Internet, ou à relação face a face, ou uma combinação entre os modos on e off-line de comunicação. No final das contas a comunidade local de Porto Alegre, por exemplo, em se tratando de jovens classe média, ${ }^{23}$ está combatendo a individualização e a atomização praticando um vivência intermediada pelos computadores.

\section{Conclusão}

Pesquisando a sociabilidade mediada por computador e realizada via Internet, a partir de chat de comunicação, percebi uma série de questões. A principal delas talvez seja o estreitamento das dimensões on e off-line, que marca a vivência dos internautas. O chat adquire o status de lugar, como se fosse um entre tantos outros pontos de encontro da cidade. ${ }^{24} \mathrm{~A}$ vivência do indivíduo no ciberespaço é tão dramática, emotiva e complexa quanto a interação face a face. Além disso, a própria interação face a face é desejada pelos internautas. Em todo o momento ficou clara uma propensão que eles têm de interagirem, a partir do encontro virtual em chat, face a face em um segundo momento. E essa não é uma questão que deva ser naturalizada e deixada de lado. Se existe na representação simbólica dos internautas uma aproximação entre modos on e off-line de vivência, e uma busca, via Internet, do encontro pessoal (compartilhando territórios da cidade), então alguma coisa ocorre diferentemente do até então pregado por alguns pesquisadores do tema.

A experiência brevemente trazida aqui nos faz refletir sobre a estreita associação que atualmente se processa entre computador/Internet e condu-

\footnotetext{
${ }^{23}$ Gradativamente outros segmentos também vão aderindo à vivência on-line.

${ }^{24}$ No caso estudado, a cidade de Porto Alegre.
} 
tas sociais. Um dos aspectos mais claros está relacionado ao cultivo de um tipo de sociabilidade que podemos denominar como sendo "virtual". Esse conceito surge do encontro de determinadas características. De um lado temos a presença de práticas de sociabilidade ao "modo clássico", sendo mantida pelo encontro face a face. De outro, está presente a especificidade gerada por tal tecnologia: a presença da interface gráfica como mediador do encontro social.

Pesquisar tal panorama significa dar conta de um fenômeno urbano. É quando o interesse de classe e a busca por um consumo de estilo de vida passa por uma apropriação da tecnologia digital. O computador/Internet é apropriado como uma ferramenta que proporciona a interação em forma de rede social, seja na inserção em forma de turma com trocas cotidianas virtuais, seja pela possibilidade de cultivo de sociabilidade lúdica na freqüência a espaços coletivos e públicos, como bares e praças em circuitos urbanos. A prática do lazer e da sociabilidade lúdica como a boemia passa por essa dimensão. Retomando o importante conceito de Simmel (1994)sobre sociabilidade lúdica para tratar do fenômeno moderno, não é mais possível pensarmos conceitualmente as relações sociais no contexto urbano portoalegrense sem dar conta das dinâmicas promovidas pela sociabilidade virtual via Internet.

\section{Referênncias}

BARNES, J. A. Redes sociais e processo político. In: FELDMANBIANCO, Bela (Org.). Antropologia das sociedades contemporâneas: métodos. São Paulo: Global Universitária, 1987. p. 159-189.

BOURDIEU, Pierre. O poder simbólico. Lisboa: DIFEL, 1989.

CARVALHO, Sérgio Lage T. de. Lonely sweet home: solidão e modernidade. Dissertação (Mestrado em Sociologia)-Faculdade de Filosofia, Letras e Ciências Humanas, Universidade de São Paulo, São Paulo, 1995.

CASTELLS, Manuel. La era de la información: economía, sociedad y cultura: la sociedad red. Madrid: Alianza Editorial, 1998. v. 1.

CASTELLS, Manuel. A era da informação: economia, sociedade e cultura: o poder da identidade. São Paulo: Paz e Terra, 1999. v. 2. 
DORNELlES, Jonatas. Planeta Terra, Cidade Porto Alegre: uma etnografia entre internautas. Dissertação (Mestrado em Antropologia Social)-PPGAS, Universidade Federal do Rio Grande do Sul, Porto Alegre, 2003. FEATHERSTONE, Mike. Cultura de consumo e pós-modernismo. São Paulo: Studio Nobel, 1995.

GEERTZ, Clifford. A interpretação das culturas. Rio de Janeiro: LTC, 1989. GIDDENS, Anthony. As conseqüências da modernidade. São Paulo: Editora da UNESP, 1991.

JOHNSON, Steven. Cultura da interface: como o computador transforma nossa maneira de criar e comunicar. Rio de Janeiro: Jorge Zahar, 2001.

JUNGBLUT, Airton Luiz. Nos chats do Senhor: um estudo antropológico sobre a presença evangélica no ciberespaço brasileiro. Tese (Doutorado em Antropologia Social)-PPGAS, Universidade Federal do Rio Grande do Sul, Porto Alegre, 2000.

MAFFESOLI, Michel. O tempo das tribos: o declínio do individualismo nas sociedades de massa. Rio de Janeiro: Forense-Universitária, 1987.

MAGNANI, J. Festa no pedaço. São Paulo: Brasiliense, 1984.

MAGNANI, José Guilherme C.; TORRES, Lilian de Lucca (Org.). Na metrópole: textos de antropologia urbana. São Paulo: Fapesp, 2000.

QUÉAU, Philippe. O tempo do virtual. In: PARENTE, André (Org.). Imagem máquina. Rio de Janeiro: Editora 34, 1993. p. 91-99.

RIETH, Flávia. A iniciação na juventude de mMulheres e homens, Pelotas (RS). Tese (Doutorado em Antropologia Social)-PPGAS, Universidade Federal do Rio Grande do Sul, Porto Alegre, 2000.

SCHUCH, Patrice. Carícias, olhares e palavras: uma etnografia sobre o "ficar" entre jovens universitários de Porto Alegre/RS. Dissertação (Mestrado em Antropologia Social)-PPGAS, Universidade Federal do Rio Grande do Sul, Porto Alegre, 1998.

SCHUTZ, Alfred. O mundo das relações sociais. In: WAGNER, Helmut R. (Org.). Fenomenologia e relações sociais: textos escolhidos de Alfred Schutz. Rio de Janeiro: Jorge Zahar, 1979. p. 123-193.

SIMMEL, Georg. Sociabilidade: um exemplo de sociologia pura ou formal. In: MORAES FILHO, E. (Org.). Simmel. São Paulo: Ática, 1996. p. 165-181. 